\title{
Peningkatan Kemampuan Guru SMKS Kesehatan Bojongsoang Membuat Perencanaan Pembelajaran Berorientasi Aktivitas Siswa Melalui Supervisi Akademik Model Kreatif
}

\author{
Lukman \\ Pengawas Madya SMK Dinas Pendidikan Propinsi Jawa Barat \\ lukmansr84@gmail.com
}

\begin{abstract}
Abstrak
Pembelajaran bermakna merupakan kegiatan pembelajaran yang menitikberatkan pada kegunaan pengalaman belajar bagi kehidupan nyata siswa. Dalam hal ini pengalaman belajar menekankan pada siswa belajar secara aktif dengan memberikan motivasi yang tinggi. Kegiatan belajar akan terasa hidup dan menyenangkan ketika aktivitas siswa dilibatkan secara optimal, menggunakan Pendekatan Pembelajaran Berorientasi Aktivitas Siswa (PBAS). Namun kenyataannya di lapangan hasil studi pendahuluan pada guru di sekolah binaan melalui observasi, angket dan studi dokumentasi RPP yang dibuat sebagian guru belum menggunakan PBAS, padahal Kompetensi Dasar (KD) yang dapat menggunakan PBAS relatif cukup banyak. Oleh karena itu, perlu adanya supervisi akademik khususnya pembinaan, dengan menggunakan model supervisi kreatif yang dilakukan oleh pengawas sekolah, supaya guru dapat membuat perencanaan pembelajaran berorientasi PBAS. Metode penelitian yang digunakan adalah penelitian tindakan sekolah mengunakan sistem spiral refleksi model Kemmis dan Mc Taggart yang dimodifikasi. Strategi/metode kerja/teknik pembinaan yang digunakan dari siklus I sampai siklus II menggunakan sistem in-on-in dengan menerapkan model supervisi kreatif. Hasil pembinaan pada siklus I menunjukkan bahwa, aktivitas guru dalam membuat RPP berbasis PBAS belum memuaskan. Oleh karena itu, kemampuan dan keahlian serta aktivitas guru pada siklus I, perlu ditingkatkan dan harus diperbaiki pada siklus II. Siklus II, mengakhiri proses pembinaan pada guru melalui supervisi kreatif, dengan indikator aktivitas guru telah diatas $75.00 \%$ dan skor guru minimal 75.00 sudah diatas $85 \%$.
\end{abstract}

Kata kunci: supervisi model kreatif, kemampuan, perencanaan pembelajaran pembelajaran berorientasi aktivitas siswa 


\section{PENDAhuluan}

Pendekatan dalam proses pembelajaran di arahkan untuk meningkatkan kualitas pembelajaran agar lebih bermakna. Pembelajaran bermakna merupakan kegiatan pembelajaran yang menitikberatkan pada kegunaan pengalaman belajar bagi kehidupan nyata siswa. Dalam hal ini pengalaman belajar menekankan pada siswa belajar secara aktif dengan memberikan motivasi yang tinggi (Osborn, 1997; Nakamura, 2001; dan Lazear 2004)

Keterlibatan aktivitas siswa dalam kegiatan belajar akan merangsang mereka untuk berpikir dan bertindak. Kegiatan belajar akan terasa hidup dan menyenangkan ketika aktivitas siswa dilibatkan secara optimal (Lazear, 2004 dan Juniarwati, 2006). Pembelajaran bermakna dapat di arahkan dengan menggunakan pendekatan yang berorientasi pada aktivitas siswa yaitu pendekatan Pembelajaran Berorientasi Aktivitas Siswa (PBAS) (Osborn, 1997 dan Juniarwati, 2006).

Pendekatan Pembelajaran Berorientasi Aktivitas Siswa (PBAS) sebagai salah satu bentuk inovasi dalam memperbaiki kualitas proses belajar mengajar bertujuan untuk membantu peserta didik agar bisa mandiri dan kreatif, sehingga ia dapat memperoleh pengetahuan, keterampilan, dan sikap yang dapat menunjang terbentuknya kepribadian yang mandiri (Osborn, 1997; Lazear, 2004; dan Juniarwati, 2006). Berdasarkan penjelasan di atas mendorong peneliti telah melaksanakan penelitian tindakan sekolah untuk meningkatkan kemampuan guru SMKS Kesehatan Bojongsoang dalam membuat RPP berbasis PBAS melalui supervisi akademik menggunakan model supervisi kreatif

\section{II.METODOLOGI PENELITIAN}

\section{Strategi/Metode Kerja/Teknik Pembinaan}

Strategi/metode kerja/teknik pembinaan yang digunakan dari siklus I sampai siklus II menggunakan model supervisi kreatif. Pada siklus 1 melalui observasirefleksi-rekomendasi, studi dokumentasi, angket dan FGD, sedangkan siklus 2 melalui observasi-refleksi-rekomendasi, studi dokumentasi angket, FGD, dan presentasi produk RPP

\section{Setting/Lokasi/Subyek Penelitian}

Secara garus besar, prosedur siklus dilakukan melalui kegiatan perencanaan (plan), siklus (act), observasi (observe) dan refleksi (reflect) (Rusefendi, 1994 dan Wiriaatmadja, 1999).

\section{Subyek dan Waktu Penelitian}

Subyek penelitian dalam penelitian ini adalah guru SMKS Kesehatan Bojongsoang, jumlah guru yang diteliti sebanyak 18 guru. Penelitian dilaksanakan dari tanggal 25 juni - 23 juli 2018

\section{Instrumen Penelitian}

Untuk memperoleh data yang diharapkan, maka dalam penelitian ini digunakan instrumen sebagai berikut: 1) rencana pelaksanaan pembinaan, 2) pedoman observasi aktivitas guru, 3) daftar chek aktivitas guru, 4) instrumen evaluasi guru dalam membuat 
RPP berbasis PBAS, 5) format observasi pembinaan, 6) format diskusi balikan, 7) Daftar hadir guru

\section{HASIL PENELITIAN DAN PEMBAHASAN}

\section{A. Hasil Penelitian}

1. Deskripsi Hasil Kegiatan Pembinaan Siklus 1

1) Aktivitas Guru pada Siklus 1

Aktivitas guru pada siklus I, dapat dilihat pada Tabel 1:

Tabel 1.

Aktivitas Guru Pada Siklus 1

\begin{tabular}{|c|l|c|c|}
\hline No & \multicolumn{1}{|c|}{ Kriteria yang diamati } & Jumlah Guru & \% \\
\hline 1 & Terampil membuat RPP berbasis PBAS & 12 & 66.67 \\
\hline 2 & Terampil membuat penilaian berbasis PBAS & 11 & 61.11 \\
\hline 3 & $\begin{array}{l}\text { Terampil membuat angket respon siswa terhadap } \\
\text { penggunaan PBAS }\end{array}$ & 13 & 72.22 \\
\hline 4 & $\begin{array}{l}\text { Terampil membuat pedoman observasi aktivitas } \\
\text { siswa berbasis PBAS }\end{array}$ & 12 & 72.22 \\
\hline 5 & Terampil membuat daftar check berbasis PBAS & 13 & 66.67 \\
\hline 6 & $\begin{array}{l}\text { Terampil membuat format observasi aktivitas siswa } \\
\text { berbasis PBAS }\end{array}$ \\
\hline
\end{tabular}

Tabel 1 diatas, menunjukkan bahwa guru yang melakukan aktivitas membuat RPP berbasis PBASdengan benar, berjumlah 12 orang $(66.67 \%)$, terampil membuat penilaian berbasis PBAS sebanyak 11 orang $(61.11 \%)$, terampil membuat angket respon siswa sebanyak 13 orang (72.22\%), terampil membuat pedoman observasi aktivitas siswa berbasis PBAS sebanyak 12 orang (66.67\%), terampil membuat daftar check berbasis PBAS sebanyak 13 orang (72.22\%), dan terampil membuat format observasi aktivitas siswa berbasis PBAS sebanyak 12 orang $(66.67 \%)$.

Tabel 1 diatas menggambarkan bahwa kemampuan guru dalam dalam membuat RPP berbasis PBAS relatif perlu ditingkatkan. Hal ini disebabkan karena sebagian besar guru selalu membuat RPP berbasis metode ceramah, sehingga untuk memulai membuat RPP menggunakan model pembelajaran lain yang inovatif salah satunya PBL, relatif belum terbiasa.Selain itu pada saat membuat instrument pembelajaran lain berbasis PBAS, mulai dari membuat angket respon siswa, membuat pedoman observasi aktivitas siswa, membuat daftar check, dan membuat format observasi aktivitas siswa guru belum terbiasa

2) Evaluasi Kemampuan Guru dalam membuat RPP berbasis PBAS yang sesuai dengan tuntutan Permendikbud No 22 Tahun 2016 tentang Standar Proses pada Siklus I

Kemampuan guru dalam membuat membuat RPP berbasis PBAS yang sesuai dengan tuntutan Permendikbud No 22 Tahun 2016, tentang Standar Proses pada siklus I, dapat dilihat pada Tabel 2. 
Tabel 2.

Jumlah Komponen RPP Berbasis PBAS yang Dipenuhi oleh Guru (dari Total 20 Komponen RPP yang Sesuai dengan Tuntutan Permendikbud No 22 Tahun 2016) pada Siklus I

\begin{tabular}{|c|c|c|c|}
\hline No & Kode Guru & $\begin{array}{c}\text { Jumlah komponen RPP berbasis } \\
\text { PBAS yang Dipenuhi oleh Guru (dari } \\
\text { total 20 komponen RPP) }\end{array}$ & $\%$ \\
\hline 1 & AA & 15 & 83,33 \\
\hline 2 & AB & 11 & 61,11 \\
\hline 3 & AC & 12 & 66,67 \\
\hline 4 & AD & 15 & 83,33 \\
\hline 5 & AE & 14 & 77,78 \\
\hline 6 & AF & 13 & 72,22 \\
\hline 7 & AG & 16 & 88,89 \\
\hline 8 & AH & 13 & 72,22 \\
\hline 9 & AI & 13 & 72,22 \\
\hline 10 & AJ & 13 & 72,22 \\
\hline 11 & AK & 16 & 88,89 \\
\hline 12 & AL & 14 & 77,78 \\
\hline 13 & AM & 16 & 88,89 \\
\hline 14 & AN & 15 & 83,33 \\
\hline 15 & AO & 14 & 77,78 \\
\hline 16 & AP & 11 & 61,11 \\
\hline 17 & AQ & 14 & 77,78 \\
\hline 18 & AR & 15 & 83,33 \\
\hline & Rata-rata & 14 & 77.78 \\
\hline & & & 61.11 \\
\hline
\end{tabular}

Data pada Tabel 2 menunjukkan bahwa jumlah komponen terkecil RPP berbasis PBAS yang dipenuhi guru, dari total 20 komponen RPP yang sesuai dengan tuntutan Permendikbud No 22 Tahun 2016, pada Siklus I sebanyak 11 komponen $(55.00 \%)$ dilakukan oleh dua orang guru $(11.11 \%)$. Sedangkan jumlah komponen terbanyak yang dipenuhi guru sebanyak 16 komponen $(80.00 \%)$ dilakukan oleh tiga orang guru $(16.67 \%)$. Rata-rata jumlah komponen yang dipenuhi guru sebanyak 14 komponen $(70.00 \%)$ dengan daya serap klasikal sebesar $61.11 \%$.

\section{3) Refleksi dan Revisi Siklus 1}

Pembinaan pada siklus I, menunjukkan bahwa pada siklus pertama menunjukkan kelebihan dan kekurangan. Kelebihannya yaitu, peneliti mulai menerapkan langkah-langkah pembinaan sesuai dengan rencana pembinaan siklus I yang telah dibuat peneliti, kemudian guru sangat antusias untuk meningkatkan kemampuannya dalam membuatRPP berbasis PBAS. Kekurangan yang ada pada pelaksanaan siklus 1 diantaranya:

- Peneliti kurang mengeksplore potensi guru untuk mengembangkan kemampuannya dalam membuat RPP berbasis PBAS, dengan menugaskan guru mencari di berbagai sumber yang relevan.

- Pemberian motivasi dan apresiasi pada saat akan melakukan pembinaan oleh peneliti masih harus ditingkatkan 
- Pada saat melaksanakan pembinaan, peneliti masih dominan di barisan paling depan, serta kurang intensif melakukan pembinaan yang komunikatif dengan guru, terutama pada saat guru mengalami kesulitan dalam membuat RPP

Berdasarkan kekurangan yang ada pada pelaksanaan siklus 1, maka pelaksanaan pembinaan pada siklus II, perlu memperhatikan perbaikanperbaikan seperti di bawah ini :

- Peneliti harus mengeksplore potensi guru untuk mengembangkan kemampuannya dalam membuat RPP berbasis PBAS

- Peneliti harus memberikan motivasi dan apresiasi pada saat akan melakukan pembinaan

- Peneliti pada saat melaksanakan pembinaan harus intensif dan komunikatif, dengan mendatangi setiap guru yang mengalami kesulitan, terutama pada saat menguasai teori belajar, khususnya dalam membuat RPP berbasis PBAS

\section{Deskripsi Hasil Kegiatan Pembinaan Siklus II}

\section{1) Aktivitas Guru pada Siklus II}

Proses pembinaan pada siklus II telah memperlihatkan adanya peningkatan aktivitas guru dibanding pada siklus I, mulai dari membuat RPP untuk setiap siklus, membuat penilaian untuk setiap siklus, membuat angket respon siswa, membuat pedoman observasi aktivitas siswa, membuat daftar check, membuat format observasi aktivitas siswa, membuat format observasi pelaksanaan model pembelajaran oleh guru dan siswa, dan membuat format diskusi balikan. Aktifitas guru selama pembinaan pada siklus II dapat dilihat dari Tabel 3

Tabel 3.

Aktivitas guru pada Siklus II

\begin{tabular}{|c|c|c|c|}
\hline No & Kriteria yang diamati & Jumlah Guru & $\%$ \\
\hline 1 & Terampil membuat RPP berbasis PBAS & 15 & 83.33 \\
\hline 2 & Terampil membuat penilaian berbasis PBAS & 14 & 77.78 \\
\hline 3 & $\begin{array}{l}\text { Terampil membuat angket respon siswa } \\
\text { terhadap penggunaan PBAS }\end{array}$ & 16 & 88.89 \\
\hline 4 & $\begin{array}{l}\text { Terampil membuat pedoman observasi } \\
\text { aktivitas siswa berbasis PBAS }\end{array}$ & 15 & 83.33 \\
\hline 5 & $\begin{array}{l}\text { Terampil membuat daftar check berbasis } \\
\text { PBAS }\end{array}$ & 17 & 94.44 \\
\hline 6 & $\begin{array}{l}\text { Terampil membuat format observasi } \\
\text { aktivitas siswa berbasis PBAS }\end{array}$ & 15 & 83.33 \\
\hline
\end{tabular}

Tabel 3 diatas menunjukkan bahwa guru yang melakukan aktivitas membuat RPP berbasis PBAS dengan benar, berjumlah 15 orang $(83.33 \%)$,terampil membuat penilaian berbasis PBAS sebanyak 14 orang (77.78\%), terampil membuat angket respon siswa sebanyak 16 orang (88.89\%), terampil membuat pedoman observasi aktivitas siswaberbasis PBAS sebanyak 15 orang (83.33\%), terampil membuat daftar check berbasis PBAS sebanyak 17 orang $(94.44 \%)$, dan terampil membuat format observasi aktivitas siswa berbasis PBAS sebanyak 15 orang (83.33\%). Tabel 3 diatas menggambarkan bahwa kemampuanguru dalam dalam membuat RPP berbasis PBAS sudah 
menunjukkan peningkatan dibanding pada siklus I, yaitu skor aktivitas minimal sudah diatas $75.00 \%$ yaitu paling kecil $77.78 \%$

2) Evaluasi Kemampuan Guru dalam membuat RPP berbasis PBAS yang sesuai dengan tuntutan Permendikbud No 22 Tahun 2016 tentang Standar Proses pada Siklus II

Kemampuan guru dalam membuat membuat RPP berbasis PBAS yang sesuai dengan tuntutan Permendikbud No 22 Tahun 2016 tentang Standar Proses pada siklus II, dapat dilihat pada Tabel 4.

Tabel 4.

Jumlah Komponen RPP Berbasis PBAS yang Dipenuhi oleh Guru (dari Total 20 Komponen RPP yang Sesuai dengan Tuntutan

Permendikbud No 22 Tahun 2016) pada Siklus II

\begin{tabular}{|c|c|c|c|}
\hline No & Kode Guru & $\begin{array}{c}\text { Jumlah komponen RPP berbasis } \\
\text { PBAS yang Dipenuhi oleh Guru (dari } \\
\text { total 20 komponen RPP) }\end{array}$ & $\%$ \\
\hline 1 & AA & 17 & 94,44 \\
\hline 2 & AB & 13 & 72,22 \\
\hline 3 & AC & 14 & 77,78 \\
\hline 4 & AD & 17 & 94,44 \\
\hline 5 & AE & 16 & 88,89 \\
\hline 6 & AF & 15 & 83,33 \\
\hline 7 & AG & 18 & 100,00 \\
\hline 8 & AH & 15 & 83,33 \\
\hline 9 & AI & 15 & 83,33 \\
\hline 10 & AJ & 15 & 83,33 \\
\hline 11 & AK & 18 & 100,00 \\
\hline 12 & AL & 16 & 88,89 \\
\hline 13 & AM & 18 & 100,00 \\
\hline 14 & AN & 17 & 94,44 \\
\hline 15 & AO & 16 & 88,89 \\
\hline 16 & AP & 13 & 72,22 \\
\hline 17 & AQ & 16 & 88,89 \\
\hline 18 & AR & 17 & 94,44 \\
\hline & Rata-rata & 88.89 \\
\hline & & 16 & 88.89 \\
\hline
\end{tabular}

Data pada Tabel 4 menunjukkan bahwa jumlah komponen terkecil RPP berbasis PBAS yang dipenuhi guru, dari total 20 komponen RPP yang sesuai dengan tuntutan Permendikbud No 22 Tahun 2016, pada Siklus II sebanyak 13 komponen $(65.00 \%)$ dilakukan oleh dua orang guru $(11.11 \%)$. Sedangkan jumlah komponen terbanyak yang dipenuhi guru sebanyak 18 komponen (90.00\%) dilakukan oleh tujuh orang guru (38.89\%). Rata-rata jumlah komponen yang dipenuhi guru sebanyak 17 komponen $(85.00 \%)$, dengan rata-rata sebesar 88.89. Indikator daya serap klasikal sudah diatas $85,00 \%$ yaitu sebesar $88.89 \%$, maka siklus II ini mengakhiri penelitian tindakan sekolah proses pembinaan pada guru melalui supervisi kreatif.

\section{B. Pembahasan}




\section{Pengaruh Pembinaan Terhadap Peningkatan Aktivitas Guru dari Siklus I - Siklus II}

Hasil pembinaan dengan menggunakan model supervisi kreatif dari siklus I sampai siklus II, menunjukkan bahwa aktivitas guru semakin aktif, serta antusias mengikuti setiap sesi pembinaan. Hampir semua guru berperan aktif mulai dari membuat RPP berbasis PBAS untuk setiap siklus, membuat penilaian berbasis PBAS untuk setiap siklus, membuat angket respon siswa, membuat pedoman observasi aktivitas siswa, membuat daftar check, dan membuat format observasi aktivitas siswa. Walaupun pada awalnya banyak yang belum terampil tetapi pada siklus II sudah menunjukkan kemajuan yang sangat pesat. Kondisi tersebut menunjukkan bahwa penggunaan model supervisi kreatif dapat meningkatkan aktivitas dan kemampuan guru dalam melaksanakan tugas pokok dan keprofesian dalam merencanakan pembelajaran yang baik dan bermutu. Hal ini sejalan dengan pendapat Yager et al, (1993) dan Trowbribge, \& Bybee, (1990), bahwa supervisi model kreatif merupakan model inovasi berdasarkan rujukan teknik, atau model-model supervisi lainnya. Model ini baik dalam membangun hubungan tatap muka antara supervisor dan guru, sehingga tujuan untuk pengembangan profesional guru dapat terwujud. Kegiatan Supervisi kreatif ditekankan pada aspekaspek yang menjadi perhatian guru serta observasi kegiatan pengajaran di kelas, observasi dilakukan secara cermat dan mendetail, analisis terhadap hasil observasi harus dilakukan bersama antara supervisor dan guru dan hubungan antara supervisor dan guru harus bersifat kolegial dan harmonis

\section{Pengaruh Diterapkannya Pembinaan terhadap Kemampuan dan Keterampilan Guru dalam Menguasai Teori Belajar, khususnya dalam Membuat RPP Berbasis PBAS.}

Hasil pembinaan dengan menggunakan model supervisi kreatif dari siklus I sampai siklus II, menunjukkan adanya peningkatan. Peningkatan tersebut menunjukkan bahwa setiap guru telah melaksanakan dan mengikuti tahap-tahap jalannya kegiatan pembinaan, serta menunjukan bahwa hampir semua guru berperan aktif mengikuti setiap sesi pembinaan yang dilakukan oleh peneliti. Selain itu, proses bimbingan dan arahan selama kegiatan pembinaan yang dilakukan sudah diupayakan efektif, efisien dan intensif. Sehingga guru tidak mengalami kesulitan dalam melaksanakan kegiatan pembinaan. Sehingga pada saat dilaksanakan pengukuran kemampuan dan keterampilan guru dalam dalam membuat RPP berbasis PBAS, pada siklus II, daya serap klasikal sudah diatas 85\%. Data tersebut menjadi indikator siklus II ini mengakhiri penelitian tindakan sekolah, kegiatan pembinaan pada guru melalui penggunaan model supervisi kreatif. Kondisi tersebut menunjukkan bahwa penggunaan model supervisi kreatif dapat meningkatkan keterampilan guru dalam membuat perencanaan pembelajaran yang bermutu. Hal ini sejalan dengan pendapat Satori, (2012) dan Yager et al, (1993), bahwa supervisi model kreatif merupakan model inovasi yang membantu guru mengembangkan keterampilan guru mempersiapkan rencana pembelajaran untuk mencapai tujuan pembelajaran, serta membantu guru mengembangkan kemampuan profesionalismenya. 


\section{SIMPULAN DAN REKOMENDASI}

\subsection{Simpulan}

1) Hasil pembinaan pada siklus I, menunjukkan bahwa aktivitas guru dalam membuat RPP berbasis PBAS, membuat penilaian, membuat angket respon siswa, membuat pedoman observasi aktivitas siswa, membuat daftar check, membuat format observasi aktivitas siswa, membuat format observasi pelaksanaan model pembelajaran oleh guru dan siswa, dan membuat format diskusi balikan belum memuaskan. Kemampuan dan keahlian serta aktivitas guru dalam siklus I, perlu ditingkatkan dan harus diperbaiki pada siklus II.

2) Hasil pembinaan pada siklus II, menunjukkan bahwa aktivitas guru mulai dari membuat RPP berbasis PBAS, membuat penilaian, membuat angket respon siswa, membuat pedoman observasi aktivitas siswa, membuat daftar check, membuat format observasi aktivitas siswa, membuat format observasi pelaksanaan model pembelajaran oleh guru dan siswa, dan membuat format diskusi balikan sudah meningkat dan lenih baik dibanding siklus I. Siklus II ini mengakhiri penelitian tindakan sekolah, proses pembinaan pada guru menggunakan model supervisi kreatif melalui observasi-refleksi-rekomendasi, studi dokumentasi angket, FGD, dan presentasi produk RPP, dengan indikator aktivitas guru telah diatas $70.00 \%$ dan skor guru minimal 70.00 sudah diatas $85 \%$, yaitu sebesar $88.24 \%$.

\subsection{Rekomendasi}

1) Model pembinaan ini, karena telah efektif meningkatkan kemampuan dan keterampilan guru dalam membuat RPP berbasis PBAS, oleh karena itu penerapannya tidak hanya di salah satu sekolah binaan, tetapi bisa diterapkan pada SMA lainnya baik negeri maupun swasta. Sehingga peningkatan pembinaan dapat terjadi secara menyeluruh

2) Bagi pengawas lainnya model pembinaan ini bisa dijadikan salah satu model pembinaan yang dapat digunakan untuk meningkatkan kemampuan dan keterampilan guru dalam membuat RPP berbasis PBAS

\section{BIBLIOGRAFI}

Juniarwati, N. (2006). Pengaruh model PBAS terhadap Hasil Belajar Siswa SMA. Skripsi UPI : tidak diterbitkan.

Lazear, D. 2004. Higher-order Thinking: The Multiple Intelligences Way. Chicago: Zephyr Press.

Nakamura, Y. (2001). The Efecktif Use of Triz With Braistorming. http : www.trizjornal.com/ achives/2001/02/index. Htm ( 7 mei 2006)

Osborn, A, F. (1997). About Brainstorming. Hppk : // www.ciadvertising.org/studies/student/97 fall/practitisioner/Osborn/afOsborn.htm. (7 mei 2006).

Permendikbud No. 20 Tahun 2016 tentang Standar Kompetensi Lulusan 
Permendikbud No. 21 Tahun 2016 tentang Standar Isi

Permendikbud No. 22 Tahun 2016 tentang Standar Proses

Permendikbud No. 24 Tahun 2016 tentang KI dan KD

Permendikbud Nomor 23 Tahun 2016 tentang Standar Penilaian

Permendikbud No. 143 Tahun 2014 tentang Petunjuk Teknis Jabatan Fungsional Pengawas Sekolah dan Angka Kreditnya

Permeneg PAN \& RB No.21 tahun 2010 tentang Jabatan Pengawas\&Angka Kreditnya

Polamato, S.W. Dj. (2005). Pengaruh Penerapan Model Traffinger pada dalam Mengembangkan Kemampuan Kreatif dan Pemecahan Masalah Siswa. Disertasi UPI : tidak diterbitkan.

Rusefendi. E.T. (1994). Dasar-dasar Penelitian Pendidikan dan Bidang

NonEksakta Lainnya. Semarang : CV. INIP semarang Press.

Salpeter. 2001. Century skill: Have Student Ready. [Online]. Tersedia: http://www.21st Centuryskill.org. [19 September 2008]

Satori, D. (2012). Sistem Penjaminan dan Peningkatan Mutu Pendidikan. Makalah: tidak diterbitkan

Suparno, P. (1997) Filsafat Konstrukstifisme dalam Pendidikan. Yogyakarta : Kanisius.

Trowbribge, L. W. \& Bybee, R. W. (1990). Becoming A secondary School Science Teacher. Fifth Ed. Columbus : Merrill Publishing A Bell \& Howell Information Co

Wahyudi. (2006). Tingkatan Pemahaman Siswa terhadap Materi Pembelajaran. http//www. Depsiknas.go.id/jurnal/36/tingkatan pemahaman siswa htm. (7 mei 2006).

Wiriaatmadja, 1999. Penelitian Kelas dalam Bentuk Penelitian Tindakan Sebagai Upaya Meningkatkan Kemahiran Profesional Dosen di Perguruan Tinggi. Jurnal Mimbar Penelitian. No 30/Juli. Bandung. UPI Bandung.

Yager, et al. (1993). The Changing Curriculum. Trends-Science; Applying Science Across the Curriculum. Journal of Curriculum and Supervision. 50 (8) ASCD 